\title{
An Occasion for a More Thorough Analysis: The New Findings Requirement and Congressional Power Under Section 5 of the Fourteenth Amendment After United States v. Morrison
}

\author{
Erin Rosen $\dagger$
}

\section{INTRODUCTION}

Despite my doubts about the Majority's $\S 5$ reasoning, I need not, and do not, answer the $\S 5$ question, which I would leave for more thorough analysis if necessary on another occasion.

Justice Breyer, dissenting in United States v. Morrison ${ }^{1}$

In United States v. Morrison, the Supreme Court held that Congress did not have the authority to enact $\S 13981$ of the Violence Against Women Act of 1994 ("VAWA"). ${ }^{2}$ Providing a federal forum for victims of crimes involving gender-motivated violence, $\S 13981$ was designed to compensate for state failures to prosecute such crimes. ${ }^{3}$ In Morrison, the Court held that Congress did not have the power to enact the statute under

Copyright (C) 2002 California Law Review, Inc. California Law Review, lnc. (CLR) is a California nonprofit corporation. CLR and the authors are solely responsible for the content of their publications.

$\dagger \quad$ J.D. Candidate, School of Law, University of California, Berkeley (Boalt Hall), 2002. I would like to thank my parents, my Aunt Judith, and my siblings for their encouragement and for their constant examples of inquisitiveness and creativity. Thank you to Professor Herma Hill Kay for taking me as an advisee, for her generosity with time and input on this Casenote, and for her inspiration. Thank you to Professors William Fletcher, Phillip Frickey, and Robert Post, as well as Neil Siegel, Jeff Lena, and the Notes and Comments Editors, for their incisive critiques of earlier drafts of this Article. Most of all, thank you to my friends-especially Cheng-Ling Chen, Karis Chi, Sejal Choksi, Christiana Coop, Meg Farquhar, Nils Halverson, Richard Hardack, Dana Hirschenbaum, Dan Murphy, Chris Nyland, Jay Shapiro, Hannah Silk, Ellen and Pauline Woodman, Chin Chin Yap, and the guys at Zebfor their humor, passion, and camaraderie, particularly during these recent days of deep sadness.

1. 529 U.S. 598, 666 (2000) (Breyer, J., dissenting).

2. 42 U.S.C. $\$ 13981$ (1994).

3. See infra notes 19-23 and accompanying text. 
either the Commerce Clause ${ }^{4}$ or Section 5 of the Fourteenth Amendment ("Section 5"). ${ }^{5}$ The current scholarship on Morrison's Section 5 analysis comments primarily on the majority's holding that Congress may not enact a remedy that targets private rather than state action ${ }^{6}$ and on the impact of Morrison on the institutional relationship between the Supreme Court and Congress. ${ }^{7}$ Receiving little substantive attention is the third-to-last paragraph of the majority's twenty-seven-page opinion, a paragraph short enough to cite in full:

Section 13981 is also different from these previously upheld remedies in that it applies uniformly throughout the Nation. Congress' [sic] findings indicate that the problem of discrimination against the victims of gender-motivated crimes does not exist in all States, or even most States. By contrast, the $\$ 5$ remedy upheld in Katzenbach v. Morgan ... was directed only to the State where the evil found by Congress existed, and in South Carolina $v$. Katzenbach ... the remedy was directed only to those States in which Congress found that there had been discrimination. ${ }^{8}$

In this paragraph, the majority suggests that Congress may not provide a Section 5 remedy that applies across the nation without findings of

4. U.S. Consr. art. I, § 8 .

5. U.S. CONST. amend. XIV, $\S 5$ ("The Congress shall have the power to enforce, by appropriate legislation, the provisions of this article."). In the preamble to $\$ 13981$, Congress cited Section 5 and the Commerce Clause as its bases for legislative authority:

Pursuant to the affirmative power of Congress to enact this part under section 5 of the Fourteenth Amendment to the Constitution, as well as under section 8 of Article I of the Constitution, it is the purpose of this part to protect the civil rights of victims of gender motivated violence and to promote public safety, health, and activities affecting interstate commerce by establishing a Federal civil rights cause of action for victims of crimes of violence motivated by gender.

42 U.S.C. § I398I(a) (1994).

6. See infra note $5 \mathrm{I}$ and accompanying text.

7. See Samuel Estreicher \& Margaret $\mathrm{H}$. Lemos, The Section 5 Mystique, Morrison, and the Future of Federal Antidiscrimination Law, 2000 Sup. Cr. REv. 109 (2000) (concluding that the institutional conflict can be resolved upon recognition that enhancing a constitutional guarantee by statute is not the same thing as changing it); Robert C. Post \& Reva B. Siegel, Equal Protection By Law: Federal Antidiscrimination Legislation After Morrison and Kimel, 110 YALE L.J. 441, 444-47, 456-72, 510-22 (2000) (arguing that neither federalism nor separation of powers considerations justify disturbing the "institutional ecology" between the Court and Congress such that Congress may only regulate conduct that a court would find to violate the Equal Protection Clause); Judith Resnik, The Programmatic Judiciary: Lobbying, Judging, and Invalidating the Violence Against Women Act, 74 S. CAL. L. REv. 269 (2000) (tracing the evolution of the Court's institutional relationship with Congress and describing how the Court has become more preoccupied with institutional advice-giving and matters of policy than adjudication); Tracy A. Thomas, Congress' Section 5 Power and Remedial Rights, 34 U.C. DAvis L. REv. 673 (2001) (providing a background on the unified theory of remedies and rights and an analysis of how that theory informs the roles the Supreme Court and Congress should have in dictating remedial rights for constitutional violations).

8. Morrison, 529 U.S. at 626-27. 
national (or near-national) harm. ${ }^{9}$ Perhaps the paucity of attention in recent scholarship to what appears to be a new findings requirement stems from a disbelief that the Court really means to announce such a requirement. Indeed, since the Court rejected Congress's enforcement power to enact $\S 13981$ on other grounds, ${ }^{10}$ the findings rationale was not essential to the Section 5 holding and may be deemed to be dicta. But if we entertain the possibility that the language quoted above is meant to have enduring value for subsequent cases, serious questions emerge: What would such a requirement mean for Congress's power under Section 5 ? How would such a requirement influence determinations of the appropriateness of congressional legislation? And how would the requirement affect the analysis of equal protection in the realm of gender? Recognizing the breadth and complexity of the issues at stake, this Casenote offers the first comprehensive response to these questions. ${ }^{11}$

Serving as the backbone of this Casenote is Section 5 of the Fourteenth Amendment, which reads: "The Congress shall have power to enforce, by appropriate legislation, the provisions of this article."12 Employing an elemental analysis by which each clause of Section 5 is

9. Id.

10. The Court also rejected $\S 13981$ as exceeding Congress's Section 5 power since the remedy applied to private, not state, conduct. See infra note 51 and accompanying text.

11. Where the findings requirement is discussed in the scholarship following Morrison, it has been mentioned only briefly or in footnotes to the main text. See, e.g., Chrystal Bobbitt, Domestic Sovereign Immunity: A Long Way Back to the Eleventh Amendment, 22 WHITTIER L. REV. 531, 574 $\mathrm{n} .339$ (2000) (noting that the findings requirement exemplifies the Supreme Court's commitment to states' rights but highlighting only the Court's treatment of findings with regard to the Commerce Clause holding); A. Christopher Bryant \& Timothy J. Simeone, Remanding to Congress: The Supreme Court's New "On the Record" Constitutional Review of Federal Statutes, 86 CORNell L. REV. 328, $342-44, n .96, n .161$ (2001) (focusing on the Court's treatment of congressional findings in the Commerce Clause holding and mentioning the Equal Protection Clause findings requirement in footnotes); Evan H. Caminker, Private Remedies for Public Wrongs Under Section 5, 33 Loy. L.A. L. REV. 1351, $1363 \mathrm{n} .41$ (noting the findings requirement and offering concern about the propriety of such a strict congruence and proportionality test); Estreicher \& Lemos, supra note 7, at 156-57 (asserting that, given Oregon v. Mitchell, 400 U.S. 112, 131-34 (1970) (upholding a nationwide ban on all literacy tests based on evidence that did not document discrimination in every state but that suggested discrimination on account of color and race is "a serious national dilemma that touches every comer of our land." Id. at 133.), the Court is incorrect to say that the remedy in VAWA was different from legislation in other cases); Julie Goldscheid, Umited States v. Morrison and the Civil Rights Remedy of the Violence Against Women Act: A Civil Rights Law Struck Down in the Name of Federalism, 86 CORNELL L. REV. 109, 128-29, 129-35 (2000) (arguing that the Court's interpretation of Congress's findings, primarily with regard to the Commerce Clause analysis, is fiawed because it fails to recoguize that VAWA is a civil rights law, for which deference should be greater); Post \& Siegel, supra note 7, at 478-79 (arguing the same rationale as Estreicher \& Leinos, supra note 7 and further arguing that nationwide application of legislation is more desirable than state-specific application). The article coming closest to analyzing the jurisprudential flaws of the findings requirement is Thomas, supra note 7, at 737-39 (doubting that the requirement makes seuse because a legislative remedy should be more broadly applicable than a judicial remedy).

12. U.S. CONST. amend. XIV, $\S 5$. 
considered in turn, this Casenote argues that by way of the newly announced findings requirement, the Morrison majority manages in a few strokes of the pen to profoundly alter each of the three key aspects of Section 5 jurisprudence.

Following a brief description of $\S 13981$ and the Court's opinion in Morrison, the Casenote's discussion begins in Part II with the element mentioned in the first clause of Section 5: Congress's power. Part II.A describes the landmark Enforcement Clause cases and demonstrates how the Court's perception of Congress's Section 5 power relies on two fundamental principles: the notion that Congress should have the power to enact prophylactic legislation (hereinafter, the "prophylactic rationale") and the idea that Congress has the power to enforce the provisions of the Fourteenth Amendment as those provisions are conceived by the Court (hereinafter, the "enforcement rationale"). Part II.B analyzes how Morrison changes the Court's characterization of Congress's Section 5 power both threatens the rationales underlying the foundational cases.

Part III discusses the element mentioned in the second clause of Section 5: appropriate legislation. Part III.A provides a description of the evolution of the Court's current two-prong test for appropriate legislation, the "congruence and proportionality" test. The Casenote proceeds to cxamine the meaning of each prong of the test and argues that together the two prongs preserve the prophylactic and enforcement rationales described in Part II.A. Part III.B evaluates the implications of Morrison's findings requirement for the two rationales and for the type of legislation the Court will consider to be appropriate.

In Part IV, the analysis turns to the last clause of Section 5: the provisions of this article."13 For Morrison, "this article" refers to the Fourteenth Amendment and the relevant "provision" is the Equal Protection Clause. ${ }^{14}$ Part IV describes the rules Congress must follow to enact prophylactic gender legislation under the Fourteenth Amendment and argues that Morrison's findings requirement makes this enactment difficult, if not impossible. This Part concludes with conjectures on how the findings requirement may change the analysis lower courts employ for Section 1 litigants.

The Conclusion discusses the ramifications of Morrison and offers justification for declining to follow Morrison's reasoning. Representing a disturbing departure from the Court's earlier Section 5 jurisprudence, the

13. Id.

14. The Equal Protection Clause provides: "No State shall ... deny to any person within its jurisdiction the equal protection of the laws." U.S. CONST. amend. XIV, $\S 1$. For the purposes of this Casenote, I use the terms "equal protection" and "Section 1" interchangeably. 
findings requirement should not be afforded precedential value and should not be used to prevent the enactment of prophylactic legislation.

Some might say that the single paragraph at issue here cannot possibly have the extensive implications this Casenote suggests. Indeed, the Court has never directly stated that Congress's Section 5 power is dependent on findings. ${ }^{15}$ Yet contemporary scholarship and case history suggests otherwise. The literature notes a trend in the Court's jurisprudence toward turning Congress into a factfinder and imposing heightened scrutiny on the congressional findings. ${ }^{16}$ Likewise, recent Section 5 cases show a measured attack on congressional power to legislate that the Court justifies in part by the lack of a congressional record. ${ }^{17}$ The findings requirement articulated in

15. See Morrison, 529 U.S. at 666 (Breyer, J., dissenting) ("This Court has not previously held that Congress must document the existence of a problem in every State prior to proposing a national solution."); Florida Prepaid Postsecondary Educ. Expense Bd. v. Coll. Sav. Bank, 527 U.S. 627, 654 (1999) (Stevens, J., dissenting) ("It is quite unfair for the Court to strike down Congress" [sic] Act based on an absence of findings supporting a requirement this Court had not yet articulated."); Bryant \& Simeone, supra note 11, at 331 ("[T]his decade's ... decisions impose an unexplained requirement on Congress to support the factual judgments underlying legislative action with evidence included in the legislative record."); Harold J. Krent, Turning Congress into an Agency: The Propriety of Requiring Legislative Findings, 46 CASE W. REs. L. REv. 731, 732-33 (1996) ("[T] he Court has never categorically called for findings to be made in support of all legislation raising constitutional questions; any such requirement unquestionably would fundamentally alter the relationship between the judiciary and the legislature."); Archibald Cox, Foreword: Constitutional Adjudication and the Promotion of Human Rights, 80 HARv. L. REv. 91, 105 (1966) ("No case has ever held that a record is constitutionally required.").

16. See Vikram David Amar \& Samuel Estreicher, Conduct Unbecoming of Coordinate Branch, The Supreme Court in Garrett, 4 GREEN BAG 2d 351, 355-56 (2001) (critiquing the Court's treatment of findings in Bd. of Trustees of the Univ. of Alabama v. Garrett, 531 U.S. 356 (2001)); William W. Buzbee \& Robert A. Shapiro, Legislative Record Review, 54 STAN. L. Rev. 87 (2001) (arguing that the requirement of a legislative record is antithetical to the nature of the legislative process); Neal Devins, Congressional Factfinding and the Scope of Judicial Review: A Preliminary Analysis, 50 DUKE L.J. 1169 (2001) (challenging the assumption that factfinding is not central to the judicial function and elucidating the problems that arise as a result of the Court's pushing the factfinding role onto Congress); Bryant \& Simeone, supra note 11 (describing the developinent of the trend toward greater judicial scrutiny of legislative records and arguing that such scrutimy is neither defensible nor helpful); Philip P. Frickey, The Fool on the Hill: Congressional Findings, Constitutional Adjudication, and United States v. Lopez, 46 CASE W. REs. L. REV. 695 (1996) (analyzing the evolution of the Court's use of congressional findings used as the basis for defending enactment of Congress's Commerce Clause power and offering msights on how a findings requirement might impact equal protection cases); Krent, supra note 15 (analyzing the trcatment of findings in United States v. Lopez and addressing the normative question of when the judiciary should impose such requirements); Saul M. Pilchen, Politics v. the Cloister: Deciding When the Supreme Court Should Defer to Congressional Factfinding Under the Post-Civil War Amendments, 59 NOTRE DAME L. Rev. 337, 369 (1984) (arguing that the factfinding theory of Congress's enforcement power rests on assertions that may not be true and thus that the theory should not be invoked to justify a broad reading of congressional power under the Enforcement Clauses of the Thirteenth, Fourteenth and Fifteenth Amendments).

17. See Bd. of Trustees of Univ. of Alabama v. Garrett, 531 U.S. 356 (2001) (acknowledging that while Congress had a basis for believing that states violate the equal protection rights of some disabled persons, congressional evidence was not thorough enough to justify Title I of the Americans with Disabilities Act's abrogation of state sovereigu immunity by way of Section 5 of the Fourteenth 
Morrison brings to the forefront both the Court's treatment of congressional factfinding and its handling of Congress's Section 5 power. This Casenote highlights how the findings requirement serves as a focal point for the intersecting concerns of the scope congressional power, the appropriateness of congressional legislation, and congressional atteinpts to provide for equal protection in gender.

Background: The Violence Against Women Act and UNITED STATES V. MORRISON

\section{A. $\$ 13981$ of the Violence Against Women Act: The Provision and the Findings}

From the initial report to the police through prosecution, trial, and sentencing, crimes against women are often treated differently and less seriously than other crimes.

Senate Report, \#103-138 ${ }^{18}$

Congress enacted $\S 13981$ to address the national problem of gendermotivated crime against women and to supplement deficiencies in state criminal justice systems for addressing this problem. ${ }^{19}$ Prior to VAWA's enactment, Congress conductcd a four-year inquiry into the extent of the problem of violence against women and the status of the states' record of remedying that problem. ${ }^{20}$ Congress's findings included testimony from

Amendment); Kimel v. Florida Bd. of Regents, 528 U.S. 62, 89-91 (2000) (finding that "Congress had virtually no reason to believe that state and local governments were unconstitutionally discriminating against their employees on the basis of age," and that Congress therefore "had no reason to believe that broad prophylactic legislation was necessary in this field"); Florida Prepaid, 527 U.S at 639-40 (finding that "[i]n enacting the Patent Remedy Act... Congress identified no pattern of patent infringement by the States, let alone a pattern of constitutional violations .... Congress came up with little evidence of infringing conduct on the part of the States.").

18. S. REP. No. 103-138, at 42 (1993), cited in Joseph R. Biden, Jr., The Civil Rights Remedy of the Violence Against Women Act: A Defense, 37 HARv. J. ON Legrs. 1, 36 n.207 (2000).

19. See generally Biden, supra note 18 (describing the purposes, provisions, and constitutionality of $\S 13981$ ). Section 13981 provides, "All persons within the United States shall have the right to be free from crimes of violence motivated by gender." 42 U.S.C. $\$ 13981$ (b). To enforce that right, subsection (c) of $\S 13981$ declares:

A person (including a person who acts under color of any statute, ordinance, regulation, custom, or usage of any State) who commits a crime of violence motivated by gender and thus deprives another of the right declared in subsection (b) of this section shall be liable to the party injured, in an action for the recovery of compensatory and punitive damages, injunctive and declaratory relief, and such other relief as a court may deem appropriate.

42 U.S.C. $\$ 13981$ (c).

20. See Morrison, 529 U.S. at 630-31 (Souter, J., dissenting) (stating that the congressional record included eight reports issued by Congress and congressional committees: H.R. CoNF. REP. No. 103-71 1 (1993); H.R. Rep. No. 103-395 (1993); STAFF of SeNaTe Comm. on the JudiciarY, I03D Cong., ist Sess., The Response to RaPE: Detours on the Road to EQual Justice (Comm. Print 
law enforcement officials, judges, social scientists, professors, physicians, and victims. ${ }^{21}$ In a brief to the Fourth Circuit for Brzonkala v. Virginia Polytechnic Institute and State University, ${ }^{22}$ amici law professors summarized Congress's findings:

(1) $[\mathrm{H}]$ istorically and currently, states have condoned violence agamst women; (2) states have failed to provide women adequate protection against gender-motivated violence; (3) the legacy and continuing pattern of state policy and practice remain a cause of the failure to prevent violence directed at women; and (4) state law enforcement and courts continue to fail to ensure women's right to equal protection of the laws against physical violence from either state or private actors. ${ }^{23}$

Evidenced by the endorsements of forty-one state attorneys general, state prosecutors overwhelmingly supported the legislation. ${ }^{24}$ After years of litigation in the lower courts regarding the constitutionality of $\S 13981,{ }^{25}$ the Supreme Court granted certiorari to settle the question. ${ }^{26}$

1993); S. Rep. No. 103-138 (1993); Staff of Senate Comm. on the Judiciary, IO2D CoNg., 2 D Sess., Violence Against Women: A Week in the Life of America (Comm. Print 1992); S. Rep. 102-197 (1991); Staff of Senate Comm. on the Judiciary, io2D cong., ist Sess., Violence Against Women: The Increase of Rape in America (Comm. Print 1991); S. Rep. No. 101-545 (1990)). For a description of the legislative findings, see Biden, supra note 18, at 2-5, 33-36 (2000). See also Tulin D. Acikalin, Debunking the Dichotomy of Nonintervention: The Role of the State in Regulating Domestic Violence, 74 TuL. L. REv. 1045 (2000) (chronicling the history of and the state's role in regulating domestic violence).

21. See Biden, supra note 18 , at 2.

22. 169 F.3d 820 (4th Cir. 1999) (en banc).

23. See Brief of Amici Law Professors Filed Pursuant to Rule 29 of the Federal Rules of Appellate Procedure in Support of the Constitutionality of the Violence Against Women Act at 8-10, quoted in Darold W. Killmer \& Mari Newman, VAWA: A Civil Rights Tool for Victims of GenderMotivated Violence, 28 CoLo. LAw. 77, 80 (1999).

24. See Goldscheid, supra note 11, at 119-20 (citing Crimes of Violence Motivated by Gender: Hearing Before the Subcomm. on Civil and Constitutional Rights of the House Comm. on the Judiciary, 103d Cong. 34-36 (1993) and Violence Against Women: Victims of the System: Hearing on S. 15 Before the Senate Comm. on the Judiciary, 102d Cong. (1991)).

25. Before the Supreme Court issued its Morrison opinion in May 2000, federal district courts decided twelve other cases under $\S 13981$. Ten courts upheld the constitutionality of $\S 13981: K u h n v$. Kuhn, 1999 U.S. Dist. LEXIS 11010 (N.D. 11l. 1999); Ericson v. Syracuse Univ., 45 F. Supp. 2d 344 (S.D.N.Y. 1999); Doe v. Mercer, 37 F. Supp. 2d 64 (D. Mass. 1999); Liu v. Striuli, 36 F. Supp. 2d 452 (D.R.1. 1999); Timm v. Delong, 59 F. Supp. 2d 944 (D. Neb. 1998); Anisimov v. Lake, 982 F. Supp. 531 (N.D. 11l. 1997); Doe v. Hartz, 970 F. Supp. 1375 (N.D. Iowa 1997); Crisonino v. New York City Housing Auth., 985 F. Supp. 385 (S.D.N.Y. 1997); Seaton v. Seaton, 971 F. Supp. 1188 (E.D. Tenn. 1997); Doe v. Doe, 929 F. Supp. 608 (D. Coun. 1996). Two courts found $\S 13981$ to be unconstitutional: Bergeron v. Bergeron, 48 F. Supp. 2d 628 (M.D. La. 1999), and Santiago v. Alonso, 96 F. Supp. 2d 58 (D.P.R. 2000).

26. Brzonkala v. Morrison, 527 U.S. 1068 (1999). 


\section{B. United States v. Morrison}

Both in the facts of her assault and in the institutional responses to it, Christy Brzonkala's case... in many respects typified the congressional findings on sexual assault.

Catherine MacKinnon ${ }^{27}$

\section{Factual Background}

While a student at the Virginia Polytechnic Institute ("Virginia Tech"), Christy Brzonkala met Antonio Morrison and James Crawford, two members of the varsity football team. Brzonkala claimed that Morrison and Crawford assaulted and repeatedly raped her within thirty minutes of their meeting. ${ }^{28}$ Brzonkala filed a complaint against Morrison and Crawford under Virginia Tech's Sexual Assault Policy. The university's Judicial Committee found insufficient evidence to punish Crawford, but found Morrison guilty of sexual assault and sentenced him to immediate suspension for two semesters. ${ }^{29}$ Morrison unsuccessfully appealed the committee's sanction $^{30}$ but three months after the initial decision, Virgima Tech notified Brzonkala that Morrison intended to initiate a court challenge to his suspension. ${ }^{31}$ University officials told Brzonkala that because the Sexual Assault Policy had not been widely circulated to students, the school had erred in prosecuting her complaint under that policy and that it would have to hold a second hearing. ${ }^{32}$ The university conducted the second hearing under its Abusive Conduct Policy. ${ }^{33}$ The Judicial Committee found Morrison guilty of using abusive language rather than sexual assault, and again sentenced him to a two-semester suspension. ${ }^{34}$

Morrison appealed this second sentence, and Virginia Tech's senior vice president and provost concluded that Morrison's punishment was "excessive when compared with other cases where there has been a finding of violation of Abusive Conduct Policy" and set aside Morrison's punishment. ${ }^{35}$ Virginia Tech did not inforn Brzonkala of this decision. When Brzonkala learned from a newspaper that Morrison would be returning to

27. Catherine A. MacKinnon, Disputing Male Sovereignty: On United States v. Morrison, 114 HARV. L. Rev. 135, 139-40 (2000).

28. Brzonkala v. Virginia Polytechnic Inst. and State Univ., 935 F. Supp. 779, 781-82 (W.D. Va. 1996).

29. Id. at 782 .

30. Id.

31. Morrison, 529 U.S. at 603.

32. Id.

33. Id.

34. Id.

35. Id. 
Virginia Tech for the fall 1995 semester, she dropped out of school and began her four-and-a-half year journey through the federal court system. ${ }^{36}$

\section{Procedural History}

In December 1995, Brzonkala sued Morrison, Crawford, and Virginia Tech in the United States District Court for the Western District of Virginia, ${ }^{37}$ alleging that Morrison and Crawford violated $\S 13981$ of VAWA and that Virginia Tech's handling of her complaint violated Title IX of the Education Amendments of 1972. ${ }^{38}$ The District Court dismissed Brzonkala's Title IX claims for failure to state a claim upon which relief can be granted..$^{39}$ The Court then held that Brzonkala's complaint stated a claim against Morrison and Crawford under $\S 13981$, but dismissed the complaint because it concluded that Congress lacked authority to enact the provision under either the Commerce Clause or Section 5 of the Fourteenth Amendment. ${ }^{40}$

A divided panel of the Court of Appeals reversed the District Court's ruling, reinstating both Brzonkala's Title IX hostile environment claim and her $\S 13981$ claim. $^{41}$ The full Court of Appeals then vacated the panel's opinion, reheard the case en banc, and by a 7-4 vote affirmed the District Court's ruling that Brzonkala stated a claim under $\S 13981 .{ }^{42}$ However, the court also affirmed the District Court's conclusion that Congress lacked constitutional authority to enact $\S 13981$ 's civil remedy under either the Commerce Clause or the Fourteenth Amendment. ${ }^{43}$

The en banc Fourth Circuit's Fourteenth Amendment analysis had four components. First, the court reasoned that Congress lacked authority under Section 5 of the Fourteenth Amendment to enact a remedy that does

36. Id. at 604 .

37. Brzonkala v. Virginia Polytechnic Inst. and State Univ., 935 F. Supp. 779 (W.D. Va. 1996).

38. Id. at 781. Title $\mathrm{IX}$ prohibits sex-based discrimination in federally funded educational institutions. See generally Rene Forseth, Jennifer Karam \& Eric J. Sobocinski, Progress in Gender Equity?: An Overview of the History and Future of Title $L X$ of the Educational Amendments Act of I972, 2 VILL. SPORTS \& ENT. L.J. 51 (1995).

39. Id. at 782 .

40. See id. at 785-93 (holding that Congress lacked authority to enact $\$ 13981$ under the Commerce Clause) and 793-801 (holding that Congress lacked authority to enact $\$ 13981$ under the Equal Protection Clause).

41. See Brzonkala v. Virginia Polytechnic Inst. and State Univ., 132 F.3d 949, 953 (4th Cir. 1997). Note that as to $\$ 13981$, the panel opinion by Judge Motz reversed and remanded on Commerce Clause grounds but did not address the district court's holding with regard to the Equal Protection Clause. See id. at 963-74.

42. Brzonkala v. Virginia Polytechnic Inst. and State Univ., 169 F.3d 820, 829-30 (4th Cir. 1999) (en banc).

43. Id. at 830-61 (holding that Congress lacked authority to enact $\S 13981$ under the Commerce Clause), 861-89 (holding that Congress lacked authority to enact $\S 13981$ under the Fourteenth Amendment). As in her majority opinion for the three-judge panel, Judge Motz did not address the Fourteenth Amendment issue in her en banc dissent. See id. at 905-33 (Motz, J., dissenting). 
not address state action but instead regulates purely private conduct. ${ }^{44} \mathrm{Sec}$ ond, the court found that $\S 13981$ was not "appropriate legislation" under the standards set forth by City of Boerne v. Flores ${ }^{45}$ because Congress's findings were not sufficient ${ }^{46}$ and the remedy proposed was "out of proportion to any possible unconstitutional state action at which it might conceivably be aimed." ${ }^{.47}$ Third, the opinion concluded that the legislative history of $\S 13981$ revealed that it was not enacted as a remedy for action that violates or may violate the Constitution..$^{48}$ Fourth, the opinion explained that finding $\S 13981$ to be a legitimate exercise of congressional remedial power under Section 5 would be to "disrupt the 'vital' 'federal balance,' and essentially confer upon Congress a general police power."

As described below, the Supreme Court upheld all of the en banc court's opinion except its holding that $\S 13981$ was not intended to remedy purposeful discrimination against women by state courts.

\section{The Supreme Court Opinion}

The Supreme Court held that $\S 13981$ was not constitutionally enacted under either the Commerce Clause or Section 5 of the Fourteenth Amendment. ${ }^{50}$ In its Fourteenth Amendment analysis, the Court first found that Congress did not have power to enact $\S 13981$ under Section 5 because the Fourteenth Amendment prohibits only state action, not the action of

44. See id. at $862-80$.

45. 521 U.S. 507 (1997), cited in Brzonkala, 169 F.3d at 880-89.

46. Id. at $880-86$.

47. Id. at 886 .

48. Brzonkala, 169 F.3d at 886 ("Congress did not design section 13981 as a remedy for purposeful discrimination against women by hostile state courts.").

49. Id. at 888 .

50. This Casenote does not analyze the Commerce Clause holding. For articles on the implications of Morrison's Commerce Clause holding, see Jason Everett Goldberg, Substantial Activity and Non-Economic Commerce: Toward a New Theory of the Commerce Clause, 9 J.L. \& PoL'y 563 (2001); Goldscheid, supra note 11; Lamar F. Jost, Constitutional Law-The Commerce Clause in the New Millennium: Enumeration Still Presupposes Something Not Enumerated. United States v. Morrison, 120 S. Ct. 1740 (2000), 1 WYo. L. REv. 195 (2001); Douglas W. Kmiec, Rediscovering a Principled Commerce Power, 28 PEPP. L. Rev. 547 (2001); Ernest A. Young, Dual Federalism, Concurrent Jurisdiction, and the Foreign Affairs Exception, 69 GEO. WASH. L. REv. 139 (2001); Alberto B. Lopez, Forty Yeas and Five Nays-The Nays Have It: Morrison's Blurred Political Accountability and the Defeat of the Civil Rights Provision of the Violence Against Women Act, 69 Geo. Wash. L. Rev. 251 (2001); Arthur B. Mark, I11, United States v. Morrison, The Commerce Clause and the Substantial Effects Test: No Substantial Limit on Federal Power, 34 CREIGHTON L. REv. 675 (2001); Ana Maria Merico-Stephens, United States v. Morrison and the Emperor's New Clothes, 27 J.C. \& U.L. 735 (2001); Louis J. Virelli \& David S. Leibowitz, "Federalism Whether They Want It or Not": The New Commerce Clause Doctrine and the Future of Federal Civil Rights Legislation After United States v. Morrison, 3 U. PA. J. ConST. L. 926 (2001); Jennifer L. Wethington, Constitutional Law-Commerce Clause-Violence Against Women Act's Civil Rights Remedy Exceeds Congress's Powers to Regulate Interstate Commerce. United States v. Morrison, 120 S. Ct. 1740 (2000), 23 U. ARK. LitTLE Rock L. Rev. 485 (2001). 
private individuals. ${ }^{51}$ Second, the Court concluded that Congress lacked authority to enact $\S 13981$ under Section 5 because $\S 13981$ does not have "congruence and proportionality between the injury to be prevented or reinedied and the means adopted to that end." 52 In support of this holding, the Court stated that $\S 13981$ was unconstitutional because it targeted individuals rather than states or state actors. ${ }^{53}$ Third, the Court reasoned that $\S 13981$ is an inappropriate remedy simce, unlike previously upheld remedies, the findings did not indicate that the problem of discrimination against victims of gender-motivated crimes exists in all states, or even in most states. ${ }^{54}$ Again, notably missing from the majority opinion was an affirmation of the Fourth Circuit's third holding that Congress did not design $\S 13981$ as a remedy for purposeful discrimination against women by hostile state courts.

Justices Stevens, Ginsburg, Breyer, and Souter dissented in Morrison. Both Justices Breyer and Souter wrote dissenting opinions, ${ }^{55}$ but only Justice Breyer addressed the Section 5 holding. ${ }^{56}$ In addition to questioning

51. Morrison, 529 U.S. at 621-25. The Morrison Court settled a long-standing debate regarding the ability of Congress to regulate private conduct by holding that $\S 13981$ was an invalid exercise of power under Section 5 because the limitation on congressional legislation was directed at private actors, not state actors. Id. at 621 . This Casenote does not discuss that holding or that debate. For scholarship on the topic, both pre- and post-Morrison, see Akhil Reed Amar, Substance and Method in the Year 2000, 28 PEPP. L. Rev. 601 (2001) (arguing that both precedent and an "equal citizenship" inquiry support congressional regulation of private conduct as a means to regulate state action); Akhil Reed Amar, The Supreme Court, 1999 Term, 114 HARv. L. Rev. 26, 104-08 (2000) (arguing a similar thesis as above); Biden, supra note 18, at 29, 38-40 (arguing that "the Supreme Court's Reconstruction-era decisions ... do not bar Congress from regulating private conduct as a means of remedying unconstitutional state conduct, even if not as an end im itself'); Caminker, Private Remedies, supra note 11 (arguing that federalism concerns do not justify reading Congress's Section 5 power as being precluded from regulating private behavior as a means to remedy state misconduct); Estreicher \& Lemos, supra note 7, 143-51, 157-58 (describing the imprecision of the Court's analysis that VAWA failed the state action requirement); MacKinnon, supra note 27, at 135, 152-73 (disputing the Court's holding on the basis of history, precedent, and theory); Victoria F. Nourse, Where Violence, Relationship, and Equality Meet: The Violence Against Women Act's Civil Rights Remedy, 11 WIs. WOMEN's L.J. 1, 11 (1996) (arguing that VAWA's civil rights remedy should be adjudged by the same standard as other civil rights remedies); Post \& Siegel, supra note 7, at 445, 474-78, 502-09 (arguing that the Court's holding with regard to regulation of private parties should not be read as creating a prohibition against such regulation but rather as establishing a requirement that Section 5 legislation be congruent and proportional to the constitutional violation at issue); Lawrence G. Sager, $A$ Letter to the Supreme Court Regarding the Missing Argument in Brzonkala v. Morrison, 75 N.Y.U. L. REv. 150, 153-54 (2000) (arguing that just as in Jones v. Alfred H. Mayer Co., 392 U.S. 409 (1968), where the Court held that under Section 2 of the Thirteenth Amendment Congress has authority to prohibit racially discriminatory acts by private actors in the real estate market, so too Congress should have authority under Section 5 of the Fourteenth Amendment to regulate private conduct).

52. Morrison, 529 U.S. at 625-26 (quoting Florida Prepaid Postsecondary Educ. Expense Bd. v. Coll. Sav. Bank, 527 U.S. 627, 639 (1999)).

53. Morrison, 529 U.S. at 626.

54. Id. at 626-27.

55. Id. at 628-66 (dissenting opinions).

56. Id. at 664-66 (Breyer, J., dissenting). Only Justice Souter joined Justice Breyer's opinion. Id. 
the majority's holding that Congress cannot remedy the conduct of state actors by regulating private individuals, ${ }^{57}$ Justice Breyer argued against the majority's second holding that $\S 13981$ lacked congruence and proportionality. ${ }^{58}$ Justice Breyer also cast doubt on the validity of the majority's assertion that Congress's findings did not indicate a national problem of pervasive gender-based stereotypes hampering state legal systems. ${ }^{59} \mathrm{Fi}-$ nally, Justice Breyer stated that he would leave a more thorough Section 5 analysis for another occasion. ${ }^{60} \mathrm{We}$ now turn to that analysis.

II

\section{The Nature of Congress's Power to EnForce the Provisions of SECTION I OF THE FOURTEENTH AMENDMENT}

The Court does not review the sufficiency of the evidence in the record to support congressional action.

Archibald Cox, $1966^{61}$

This Part traces the Court's conceptualization of Congress's Section 5 power. This analysis is important for appreciating how Morrison changes the Court's depiction of that power as it pertains to the enactment of all realms of legislation, including, but not limited to, gender. Since power is a nebulous concept, the endeavor to fix the point where the Court attaches a locus to the notion is problematic. Grounding the discussion here is the relationship between the Court's perception of Congress's enforcement power and the Court's deference to congressional legislation. A significant theme running through the discussion is that nowhere in the Court's prior jurisprudence has the Court's deference to Congress's enforcement power been tethered to a set of findings provided by Congress. ${ }^{62}$

Below, a narrative of four cases presents the evolution of the Court's characterization of Congress's Section 5 power. The evolution culminates in a depiction which has a sort of bipolar nature to it. On one end of the spectrum, the Court describes Congress's Section 5 power as "a positive grant of legislative power." conduct which is not itself unconstitutional,"

57. Id. at 664-65 (Breyer, J., dissenting).

58. Id. at 665 (Breyer, J., dissenting).

59. Id. at 665-66 (Breyer, J., dissenting).

60. Id. at 666 (Breyer, J., dissenting).

61. Cox, supra note 15 , at 105 (discussing the respective roles of the Supreme Court and Congress in the enforcement of the Fourteenth and Fifteenth Amendments).

62. See supra note 15.

63. Morrison, 529 U.S. at 619 (quoting Katzenbach v. Morgan, 384 U.S. 641 , 651 (1966)).

64. Id. at 619 (quoting City of Boeme v. Flores, 521 U.S. 507, 518 (1997)). 
ability to enact prophylactic legislation. ${ }^{65}$ At the other end of the spectrum, the Court characterizes Congress's power as being circumscribed by limitations such as the limitation against "decree[ing] the substance of the Fourteenth Amendment." cited by the Court, the enduring prophylactic and enforcement rationales underlying the key cases suggcst that Congress's Section 5 power is considerable. These rationales, and thus congressional power generally, are significantly threatened by Morrison's findings requirement.

A. The Court's Characterization of Congress's Section 5 Power: The Prophylactic and Enforcement Rationales

South Carolina v. Katzenbach, ${ }^{67}$ the first of the four landmark cases, illustrates the Court's conception of Congress's enforcement power as a positive grant of legislative power deserving of judicial deference. Although this case dealt with Congress's enforcement power under the Fifteenth rather than the Fourteenth Amendment, the Enforcement Clauses are nearly identical, and they serve the same function of enabling Congress to enforce the provisions of the relevant constitutional amendment. ${ }^{68}$ In South Carolina v. Katzenbach, the Court reviewed selected provisions of the Voting Rights Act of 1965, which created stringent remedies for voting discrimination where it existed on a pervasive scale and strengthened existing remedies where it was less insidious. The State of South Carolina sought a declaration that these provisions were unconstitutional because they exceeded Congress's power and encroached on an area reserved to the states by the Constitution. ${ }^{69}$ The Court held that Congress had authority to enact these provisions. ${ }^{70}$ Writing for the majority, Chief Justice Warren gave shape to his characterization of Congress's enforcement power by quoting then Chief Justice Marshall in Gibbons v. Ogden: "This power, like all others vested in Congress, is complete in itself, may be exercised to its utmost extent, and acknowledges no limitations, other than are prescribed in the constitution." ${ }^{.71}$ As conceptualized by the South Carolina v. Katzenbach Court, Congress's enforcement power was extreinely broad.

65. For the purpose of this Casenote, the term "prophylactic legislation" refers to legislation enacted to prevent specific behavior, such legislation covers "more than the core activity prohibited." Brian K. Landsberg, Safeguarding Constitutional Rights: The Uses and Limits of Prophylactic Rules, 66 TENN L. Rev. 925, 927 (1999) (quoting United States v. O'Hagan, 521 U.S. 642, 646 (1997)).

66. City of Boerne, 521 U.S. at 519.

67. 383 U.S. 301 (1966).

68. Compare U.S. ConsT, amend. XV, $\$ 2$ ("The Congress shall have power to enforce this article by appropriate legislation.") with supra text accompanying note 13.

69. See South Carolina v. Katzenbach, 383 U.S. at 307-08, 323.

70. Id. at 336 .

71. Id. at 327 (quoting Gibbons v. Ogden, 22 U.S. (9 Wheat.) 1, 196 (1824)). 
Scholars point out that South Carolina $v$. Katzenbach may signify that deference is appropriate only when congressional findings support the enactment of the legislation. ${ }^{72}$ Indeed, the provisions at issue were accompanied by an "unimpeachable" record of "voluminous data" showing racial discrimination in voting. ${ }^{73}$ Moreover, the Court referred to Congress's presentation of "reliable evidence of actual voting discrimination in a great majority of the States."74

However, the Court's analysis in the second key Enforcement Clause case, Katzenbach v. Morgan, ${ }^{75}$ indicates the Court's willingness to defer to Congress's Section 5 power even without congressional findings. Decided just three months after South Carolina v. Katzenbach, in Morgan, New York City voters unsuccessfully challenged the constitutionality of a provision of the Voting Rights Act of 1965 that appeared to preempt New York state election laws that imposed an English literacy requirement on potential voters, ${ }^{76}$ which effectively disenfranchised several hundred thousand New York City residents from Puerto Rico. ${ }^{77}$ Section 4(e) of the Voting Rights Act provided that no person who had successfully completed the sixth primary grade in a Puerto Rican school in which the predominant language was other than English would be disqualified from voting under any literacy test and thereby prohibited the enforcement of New York's literacy requirement. ${ }^{78}$ Plaintiffs sought a declaratory judgment and an injunction restraining compliance with this section of the Voting Rights Act. ${ }^{79}$ Plaintiffs had support for their position; seven years earlier, the Court had decided in Lassiter v. Northampton County Bd. of Elections ${ }^{80}$ that North Carolina's English literacy requirement was not in all circumstances prohibited by the first sections of the Fourteenth and Fifteenth Amendments. ${ }^{81}$

Despite its previous holding in Lassiter, however, the Morgan Court upheld the Voting Rights Act. Two different rationales for upholding the Voting Rights Act can be gleaned fron the opinion: a prophylactic rationale and an enforcement rationale. ${ }^{82}$

72. Bryant \& Simeone, supra note 11 , at 364-65.

73. Pilchen, supra note 16 , at 343.

74. Id. at 345 (citing South Carolina v. Katzenbach, 383 U.S. at 329).

75. 384 U.S. 641 (1966).

76. Id. at 644 .

77. Id.

78. See id.

79. Id. at 643 .

80. 360 U.S. $45(1959)$.

81. Id. at 53-54.

82. Professor Pilchen characterizes the second rationale as a "deference" rationale having the implication that Congress may define unconstitutional behavior by its own standards. For his depiction of this rationale, see Pilchen, supra note 16, at 347-51. While 1 recognize the merit of Professor 
Demonstrating the prophylactic rationale, the Morgan Court reasoned that a constitutional violation need not first occur before Congress has the ability to legislate. ${ }^{83}$ Justice Brennan explained:
A construction of $\S 5$ that would require a judicial determination that the enforcement of the state law precluded by Congress violated the Amendment, as a condition of sustaining the congressional enactment, would depreciate both congressional resourcefulness and congressional responsibility for implementing the Amendment. It would confine the legislative power in this context to the insignificant role of abrogating only those state laws that the judicial branch was prepared to adjudge unconstitutional, or of merely informing the judgment of the judiciary by particularizing the "majestic generalities" of $\S 1$ of the Amendment. ${ }^{84}$

Accordimgly, unlike South Carolina v. Katzenbach, Congress had not provided findings of unconstitutional behavior to support the enactinent of the statute at issue ${ }^{85}$ Commenting on Morgan, Professor Archibald Cox wrote, "Implicit in the reasoning is the proposition that the basis for the congressional determination need not appear in the legislative record." $\$ 66$

Indicating Morgan's enforcement rationale, the Court upheld the Voting Rights Act because it "perceive[d] a basis upon which Congress might have determined that application of New York's English literacy requirement constituted an invidious discrimination in violation of the Equal Protection Clause." ${ }^{97}$ Writing for the majority, Justice Brennan asserted that Section 5 "authoriz[es] Congress to exercise its discretion in determining whether and what legislation is needed to secure the guarantees of the Fourteenth Amendment." 88

Pilchen's interpretation, given Justice Harlan's dissent in South Carolina v. Katzenbach, infra note 90 and accompanying text, and City of Boerne's contrary holding, infra notes 107-12 and accompanying text, this Casenote asserts that this rationale is best understood as an "enforcement" rationale having two possible implications for congressional power, see infra notes $89-91$ and accompanying text, and examines the aspect of the rationale that survives after City of Boerne, infra notes 113-14 and accompanying text. See also William Cohen, Congressional Power to Interpret Due Process and Equal Protection, 27 STAN. L. REv. 603, 604-06 (1975) (describing the controversy spurred by the rationale in question).

83. Morgan, 384 U.S. at 648.

84. Id.

85. Pilchen, supra note 16 , at $348-49$ ("The findings attributed by the Court to Congress were, however, those reasonably subject to judicial notice: the group benefited by section 4(e) was a racial or ethnic minority without the right to vote. Enfranchising the minority was a rational way to prevent judicially-proscribed state discrimination from occurring.").

86. Cox, supra note 15 , at 104 . Cox further lamented, "One wishes that the point might have been treated more explicitly, for it was a major source of difference between the majority and the dissent." Id.

87. Morgan, 384 U.S. at 656.

88. Id. at 651 . 
Scholars have interpreted the enforcement rationale in two ways. First, the rationale has been taken to mean that Congress itself can determine whether unconstitutional behavior exists: "Congress... [may] legislate against a practice that it believe[s] violate[s] the Constitution, regardless of whether the Court would agree." ${ }^{\prime 89}$ Under this interpretation, the enforcement rationale implies that Congress may disregard Supreme Court precedent on the contours of unconstitutional behavior and that Congress may employ its own analysis and regulate activity it thinks might be unconstitutional. Indeed, it is possible to perceive this rationale in both South Carolina v. Katzenbach and Morgan, since the Court in these two cases upheld provisions of the 1965 Voting Rights Act which conflicted with the reasoning of the Lassiter Court. Dissenting in Morgan, Justice Harlan disagreed that the enforcement rationale should be taken as having such an implication:

[W]e have here not a matter of giving deference to a congressional estimate, based on its determination of legislative facts ... but rather what can at most be called a legislative announcement that Congress believes a state law to entail an unconstitutional deprivation of equal protection. Although this kind of declaration is of course entitled to the most respectful consideration, coming as it does from a concurrent branch and one that is knowledgeable in matters of popular political participation, I do not believe it lessens our responsibility to decide the fundamental issue of whether in fact the state enactment violates federal constitutional rights. ${ }^{90}$

The second possibility of what the enforcement rationale might mean is more in keeping with Justice Harlan's analysis. Under the second reading, as long as Congress employs the Court's legal rules, Congress has the power to adjudge a situation and determine whether constitutional behavior exists or has a likelihood of existing. Supporting this interpretation of the enforcement rationale, Professor Cox argues that Morgan should not be read as requiring the Court to defer to congressional derivation of applicable legal standards but, instead, that Morgan should be taken to mean that the Court should defer to Congress's application of the Court's own standards to questions of fact. ${ }^{\text {91 }}$

The second understanding of Morgan's enforcement rationale has endured in the post-Morgan cases. For example, in the third landmark Enforcement Clause case, City of Rome v. United States, ${ }^{92}$ the City of Rome, Georgia, sought exemption from $\S 5$ of the Voting Rights Act,

89. Pilchen, supra note 16 , at 349.

90. Morgan, 384 U.S. at 669-70 (Harlan, J., dissenting).

91. Archibald Cox, The Role of Congress in Constitutional Determinations, 40 U. CIN. L. Rev. $199,227-30$ (1971).

92. 446 U.S. $156(1980)$. 
which required pre-clearance with the U.S. Department of Justice of any change in voting standards, practices, and procedures. ${ }^{93}$ One of Rome's allegations was that the Enforcement Clause of the Fifteenth Amendment did not afford Congress the power to enact this provision of the Voting Rights Act. Rome contended that the Enforcement Clause of the Fifteenth Amendment allowed Congress only to enact legislation to reinedy violations of Section 1 of the Fifteenth Amendment that involve purposeful racial discrimination in voting, as opposed to violations that involve voting practices that are discriminatory in effect. ${ }^{94}$ While the Attorney General had findings showing discriminatory impact, he did not provide findings of intentional discrimination. ${ }^{95}$ In response to Rome's contention, the Court noted that Rome was correct that a Section 1 constitutional violation occurs only where there is purposeful racial discrimination ${ }^{96}$ and that there appeared to be no such violation in the case at hand ${ }^{97}$ Nevertheless, implementing Morgan's prophylactic and enforcement rationales, the Court held that Congress had the power to enact $\S 5$ of the Voting Rights Act because Congress could have concluded that it was proper to prohibit changes in voting practices that have a discriminatory impact where such changes are inade by jurisdictions with a demonstrable history of intentional racial discrimination..$^{98}$ As Professor Frickey explains, the second view of the enforcement rationale governs in City of Rome:

[U]nder Rome, the judiciary establishes what the law is-what the constitutional standard shall be-and then accords Congress substantial, but not complete, discretion in applying that standard to the facts of the real world... [S]o long as Congress acts reasonably to comply with judicially created constitutional standards, the Court will accord Congress the discretion to carry out its responsibilities. ${ }^{99}$

The fourth key Enforceinent Clause case, City of Boerne v. Flores, ${ }^{100}$ settled whatever question still lingered regarding which of the two readings of Morgan's enforcennent rationale should govern. At issue in City of Boerne was the Religious Freedom Restoration Act ("RFRA"), which Congress had enacted in direct response to the Court's decision in Employment Division, Dept. of Human Resources of Oregon v. Smith. ${ }^{101}$ In

93. Id. at $159-60$.

94. Id. at 172 .

95. Id. at 161-62.

96. Id. at 173 (citing City of Mobile v. Bolden, 446 U.S. 55 (1980)).

97. Id. at 172 .

98. Id. at 177.

99. Frickey, supra note 16 , at 717.

100. 521 U.S. 507 (1997).

101. 494 U.S. 872 (1990). 
Oregon v. Smith, the Court upheld an Oregon statute criminalizing the use of peyote. ${ }^{102}$ Members of the Native American Church brought an unsuccessful Free Exercise Clause claim ${ }^{103}$ after the state denied them unemployment benefits when they lost their jobs because they had used peyote. ${ }^{104}$ Contesting the Court's reasoning in Oregon v. Smith, Congress passed RFRA, which included provisions directly responding to Oregon $v$. Smith and would have allowed members of the Native American Church to win their claim. ${ }^{105}$

In City of Boerne, the Court struck down RFRA on the ground that it exceeded Congress's Section 5 power. ${ }^{106}$ The Court characterized Congress's Section 5 power as extending only to "enforc[ing]' the provisions of the Fourteenth Amendment."107 The Court explained that the activity of enforcing the provisions of the Amendment was separate from the activity of determining the substance of the provisions ${ }^{108}$ and warned that "[i]f Congress could define its own powers by altering the Fourteenth Amendment's meaning, no longer would the Constitution be 'superior paramount law." 109

Justice Kennedy explicitly acknowledged in City of Boerne that Morgan suggests that Congress has the right to interpret the constitutionality of laws or activities: "There is language in...Katzenbach $v$. Morgan...which could be interpreted as acknowledging a power in Congress to enact legislation that expands the rights contained in $\S 1$ of the Fourteenth Amendment." necessary interpretation, however, or even the best one."111 Instead, the Court ruled that Congress's role is to remedy or prevent unconstitutional actions, not to make a substantive change in the governing law. ${ }^{112}$ In othcr

102. Id.

103. See U.S. CONST. amend. 1 ("Congress shall make no law respecting an establishment of religion, or prohibiting the free exercise thereof."). The Court has understood the Fourteenth Amendment to incorporate the Free Exercise Clause. See Bryant \& Simeone, supra note 11, at 345 (citing City of Boerne, 521 U.S. at 517).

104. See City of Boerne, 521 U.S. at 514-16.

105. See id.

106. See id. at 511 .

107. Id. at 519.

108. Id. ("The design of the Amendment and the text of $\S 5$ are inconsistent with the suggestion that Congress has the power to decree the substance of the Fourteenth Amendment's restrictions on the States. Legislation which alters the meaning of the Free Exercise Clause cannot be said to be enforcing the Clause. Congress does not enforce a constitutional right by changing what the right is. It has been given the power 'to enforce' not the power to determine what constitutes a constitutional violation.") See also id. at 532 ("[RFRA] appears... to attempt a substantive change in constitutional protections.").

109. Id. at 529 (quoting Marbury v. Madison, 5 U.S. (1 Cranch) 137, 177 (1803)).

110. Id. at $527-28$.

111. Id. at 528 .

112. Id. at 519-20. 
words, the Court will not defer to Congress when Congress infringes on the Court's territory by creating its own standards for determining the constitutionality of actions.

Although the City of Boerne Court characterized its interpretation of the Morgan rationale as a limitation on congressional power, ${ }^{113}$ this Casenote contends that City of Boerne is better read as clarifying that the Court's conception of Congrcss's Section 5 power is animated by the second reading of Morgan's enforcement rationale. At the same time, City of Boerne took pains to acknowledge that Morgan's prophylactic rationale still endures, stating: "Preventative measures prohibiting certain types of laws may be appropriate when there is reason to believe that many of the laws affected by the congressional enactment have a significant likelihood of being unconstitutional."114 Thus, after City of Boerne we are left with a characterization of Congress's enforcement power as a positive grant of legislative power that is inspired by a prophylactic rationale (the ability to regulate conduct that is not unconstitutional) and an enforcement rationale (the ability to determine whether legislation is warranted by applying the Court's legal standards to a set of facts).

These two rationales provide Congress with significant power. Commenting on South Carolina v. Katzenbach in 1966, Professor Cox made the following observations about the prophylactic rationale:

It would be difficult to exaggerate the germinal importance of the key proposition in South Carolina v. Katzenbach .... To transfuse into the enforcement provision of the fifteenth amendment the familiar necessary and proper clause principle that "Congress may use any rational means to effectuate the constitutional prohibition" iniplies that under the parallel enforcement provision of the fourteenth amendment Congress may regulate activities which do not themselves violate the prohibitions of the amendment, where the regulation is a rational means of effectuating one of its prohibitions. ${ }^{115}$

As Professor Cox argues, this prophylactic power would seem to enable Congress to take sizable steps toward promoting human rights. ${ }^{116}$

Professor Cox also commented on the expansive power afforded Congress by the enforcement rationale:

For the future the decision [Morgan] logically permits the generalization that Congress... has the power to enact any law which may be viewed as a measure for correction of any condition

113. See City of Boerne, 521 U.S. at 517-20 (explaining that Congress's Section 5 power applies "only" to enforcing the provisions of the Fourteenth Amendnent).

114. Id. at 532 .

115. Cox, supra note 15 , at 102.

116. Id. at 91 . 
which Congress might believe involves a denial of equality or other fourteenth amendment rights. ${ }^{117}$

Together, the prophylactic and enforcement rationales should give Congress the power to enact legislation that that provides a prophylactic remedy in situations where there is a likelihood of unconstitutional behavior. ${ }^{118}$ Part 1I.B explains how Morrison threatens both rationales underlying Section 5 jurisprudence and Congress's Section 5 power.

\section{B. Morrison's Findings Requirement: A Threat to the Prophylactic and Enforcement Rationales Underlying Congress's Section 5 Power}

In Morrison, the Court reasoned that since $\S 13981$ was to apply uniformly throughout the nation even though Congress had only presented findings for twenty-one states, the statute differed from other provisions the Court considered to be permissible. In suggesting that Congress may not enact a national remedy without findings of national or near-national harm, the Morrison Court altered the nature of Congress's Section 5 power in three profound ways.

\section{Id. at 107.}

118. The open question is whether Congress has the ability to enact prophylactic legislation where the Court has not yet provided applicable standards to guide Congress under the enforcement rationale. In other words, may Congress legislate where the Court has not yet defined a standard applicable to the facts at hand? See Post \& Siegel, supra note 7, at 443 ("[1]t is uncertain whether and to what extent Congress can exercise its power under Section 5 to redress forms of discrimination that differ from those that courts prohibit in cases arising under Section 1 of the Fourteenth Amendment."). Justice Harlan's answer would be "no"; he argued that until a judicial determination has been made that state conduct violates the Constitution, Congress may not act. See Morgan, 384 U.S. at 666-67 (Harlan, J., dissenting). Others would argue "yes." See, e.g., Douglas Laycock, RFRA, Congress, and the Ratchet, 56 MonT. L. Rev. 145, 155 (1995) (arguing under the "ratchet theory" that Congress can increase but not reduce Constitutional protections provided by the judiciary); Post \& Siegel, supra note 7, at 444-47, (arguing for "institutional variance in legislative and judicial enforcement" of the Equal Protection Clause. Id. at 445); Pilchen, supra note 16, at 344 (arguing that the provisions in Katzenbach were controversial because "its sanctions were invoked prior to judicial determination of a constitutional violation"); Sager, supra note 51, at 151 (arguing that Congress's enforcement power under the Fourteenth Amendment should be as broad as under the Thirteenth Amendment, as exemplified by Jones v. Alfred H. Mayer Co., 392 U.S. 409 (1968), wherein the Court accepted congressional definitions of "badges and incidents of slavery" that differed from definitions previously articulated by the Court); cf. Cohen, supra note 82, at 604-06 ("1t is treacherous business, however, to bring the Court's opinion in Jones within the confines of the interpretation-remedy distinction propounded by Justice Stewart in the fourteenth amendment cases."). Using the enforcement rationale of Morgan, this Casenote aligus itself with the "yes" camp. That is, Congress may use the doctrinal tests the Court has provided to address conduct that may not yet have reached the courts but that nevertheless deserves regulation. See, e.g., Cox, supra note 15, at 98 ("A chief responsibility of counsel in constitutional litigation" or, 1 would argue, of Congress in legislation, "is to aid the Court in that mysterious process by which decisions meet new needs yet are shown to have the legal roots needed to maintain the rule of law."). Ultimately, though, this question does not pertain to the subject of this Casenote since Morrison deals with gender discrimination and the rules for detcrmining the existence of such discrimination have been articulated. See infra notes 179-81 and accompanying text. 
First, Morrison's findings requirement threatens the prophylactic rationale underlying the landmark Section 5 cases. The significance of the threat depends on what the requirement means. Since the Court was not explicit about the contours of the requirement, ${ }^{119}$ this Casenote considers two different possibilities of what the requirement might mean and how each reading endangers the prophylactic rationale.

Under the most extreme interpretation, the requirement could mean that Congress's Section 5 power is wholly dependent on a presentation of findings of unconstitutional behavior. This would suggest that Congress must demonstrate an exact one-to-one correspondence between its findings of harm and the scope of its legislation. If this is what the requirement means, then Morrison completely removes the prophylactic principle evident in the key Enforcement Clause cases. Under this reading, if Congress does not present data of unconstitutional conduct, Congress would not have powver to regulate the activity even if there is a significant likelihood of unconstitutional behavior (such as was determined in South Carolinav. Katzenbach, Morgan, and City of Rome).

Under a second interpretation, the requirement could mean that in order for Congress to have power to enact national legislation, it must present findings of unconstitutional conduct for most of the areas it wishes to regulate. Such a requirement also threatens the prophylactic rationale because it contravenes the holding of Morgan where the Court upheld congressional legislation even on a showing of almost no findings of unconstitutional behavior. Moreover, because the notion that Congress may regulate conduct that is not unconstitutional is inherent to the prophylactic rationale, a requirement that makes it more difficult for Congress to regulate such conduct infringes on the prophylactic rationale. Under this reasoning, Morrison's findings requirement does just that because it presents a high threshold upon which findings of unconstitutional conduct in certain areas may be seen to signify the likelihood of unconstitutional conduct in undocumented states. That is, only after a burdensome process of finding unconstitutional conduct in most states may Congress begin to legislate nationally. ${ }^{120}$

119. The Court said no more about the findings requirement than what is quoted at supra note 8 . The lack of detail about the contours of the findings requirement may be intentional. See Bryant \& Simeone, supra note 11 , at 348 (suggesting that the Court's evasiveness with regard to the findings requirement in City of Boerne was deliberate).

120. A third interpretation of the findings requirement exists: the Court could inean that Congress must present findings representing a likelihood of unconstitutional behavior for all the jurisdictions in which it wishes to legislate. This interpretation would seem to be in keeping with the legislation under South Carolina v. Katzenbach (since South Carolina v. Katzenbach extensive findings would satisfy this requirement, see supra notes 73-74 and accompanying text), Morgan (since the Court was persuaded that unconstitutional conduct was likely, despite the lack of findings to this extent, see supra notes 83-86 and accompanying text), and City of Rome (since the Court was persuaded that the findings 
Morrison's findings requirement also changes the nature of congressional power by threatening the enforcement rationale underlying the earlier Enforcement Clause cases. Previously, the Court deferred to congressional judgment regarding the need for legislation where it "perceive[d] a basis upon which Congress might [have] predicate[d] a judgment"121 that discrimination existed or where "Congress could rationally have concluded that"122 legislation was needed to prevent discrimination. As refined by City of Boerne, the enforcement rationale had suggested that the Court will defer to Congress if Congress employs the Court's legal rules when assessing the need for legislation.

Both readings of Morrison's findings requirement imperil this rationale. Under the first reading - where there must be a one-to-one correspondence between the scope of the harm and the scope of the remedy-the enforcement rationale is threatened because the Court will not defer to Congress unless Congress has determined that there has already been a constitutional violation; in other words, the Court will no longer simply accept Congress's judgment that legislation is warranted. Under the second reading of the requirement-where findings are required for most of the regulated states-the enforcement rationale is still threatened because even if Congress complies with the rationale and employs the Court's standards to assess the likelihood of unconstitutional behavior, Congress's judgment will not be deferred to without a factual showing of unconstitutional behavior. Under either reading of the requirement, the essence of the enforcement rationale as we saw it in Morgan and City of Boerne is lost, since in those cases Congress was not required to prove unconstitutional conduct before the Court deferred to congressional judgment.

Third, in addition to jeopardizing the prophylactic and enforcement rationales, Morrison's findings requirement also demands a fundamental change in the character of Congress's Section 5 legislative work. The findings requirement puts an affirmative duty on Congress to be the factfinder, an endeavor for which it may be well suited, ${ }^{123}$ but which nevertheless may transform Congress into the functional equivalent of a quasi-administrative

of discriminatory impact were suggestive of unconstitutional conduct, see supra notes 94-98 and accompanying text). Under this interpretation of the test, $\$ 13981$ also appears valid. See Morrison, 529 U.S. at 665-66 (Breyer, J., dissenting) ("Why can Congress not take the evidence before it as evidence of a national problem?").

121. Katzenbach v. Morgan, 384 U.S.641, 656 (1966).

122. City of Rome v. United States, 446 U.S. 156, 177 (1966).

123. But see Devins, supra note 16, at 1177-87 (arguing that the branch of government most suited to factfinding is the one with the greatest incentive to get the facts right, considering the context at hand); Pilchen, supra note 16, at 369 ("Because courts-relative to legislatures-are sheltered from politics, their factfinding ability in a particular case may exceed that of the political branch."). 
agency. ${ }^{124}$ Moreover, the imposition of a findings requirement may shift Congress's resources away from other governance activities. ${ }^{125}$

Whether its findings requirement is read broadly or narrowly, Morrison sizably restricts Congress's Section 5 power by tying that power to a findings requirement that did not exist in the earlier cases. Having established the threat Morrison places on the prophylactic and enforcement rationales underlying Congress's Section 5 power, we now examine what Congress may do with this curtailed power.

III

\section{The NATURe OF APPROPRIATE LegisLation}

Congress is authorized to enforce the prohibitions by appropriate legislation. Some legislation is contemplated to make the amendinents fully effective. Whatever legislation is appropriate, that is, adapted to carry out the objects the amendinents have im view, whatever tends to enforce submission to the prohibitions they contam, and to secure to all persons the enjoyment of perfect equality of civil rights and the equal protection of the laws against State denial or invasion, if not prohibited, is brought within the domain of congressional power.

Ex parte Virginia, $1879^{126}$

This Part begins with a description of the evolution of the Court's standard for determining whether Congress's legislation is appropriate for enactments under Section 5 . In the early Section 5 cases, the Court considered the term "appropriateness" to have as broad a sweep as it had under the Necessary and Proper Clause. ${ }^{127}$ Although the Court's definition of appropriate legislation became more nuanced with the articulation of the

124. See Krent, supra note 15 , at 733 (describing the costs and benefits of requiring legislative findings); Bryant \& Simeone, supra note 11, at 348-54 (arguing that by way of the Section 5 findings requirements in Florida Prepaid and Kimel, "the Court has, without express justification or explanation, imposed upon Congress procedural requirements akin to those imposed on federal adıninistrative agencies." Id. at 354.).

125. See Bryant \& Simeone, supra note 11, at 384 (arguing that if the Court continues to put heightened significance on formal legislative records, "the Court's approach will likely have the undesirable consequence of diverting scarce congressional resources away from the political and public-informing functions that committee hearings currently serve in order to satisfy the judiciary's increasingly rigorous demands of the legislative record"); Krent, supra note 15, at 733 (also arguing that findings "raise the cost of legislating by imposing a new layer of procedures upon Congress").

126. 100 U.S. $339,345-46$ (1879).

127. See infra notes $131-40$ and accompanying text. The Necessary and Proper Clause refers to U.S. CoNST. art. 1, $\$ 8$, cl. 18 (The Congress shall have the power " $[t]$ o make all Laws which shall be necessary and proper for carrying into Execution the foregoing Powers, and all other Powers vested by this Constitution in the Government of the United States, or in any Department or Officer thereof.'). 
"congruence and proportionality" test in City of Boerne, ${ }^{128}$ underlying the City of Boerne Court's conception of appropriate legislation were the same enforcement and prophylactic rationales that long supported the Court's conception of Congress's Section 5 power. Rather than changing these fundamental rationales, City of Boerne set in motion a methodology for determining what constitutes appropriate legislation, a methodology predicated upon distinguishing between appropriate targets of legislation and appropriate remedies for addressing those targets. ${ }^{129}$ While this distinction was present in the early cases, it did not become crucial to the analysis until after City of Boerne. ${ }^{130}$ Accompanying the emphasis on these factors was an increased reliance on findings to prove both that the target was appropriate for legislation and that the remedy was apposite. This Casenote contends that Morrison's findings requirement does not comport with the Court's previously articulated tests and rationales for appropriate legislation and thus creates new limits to the legislation that Congress may enact under Section 5.

\section{A. The Court's Characterization of Appropriate Legislation: The Prophylactic and Enforcement Rationales}

Until 1997, the Court drew its standard for determining the appropriateness of legislation from a trio of nineteenth century cases: Ex parte Virginia, ${ }^{131}$ The Civil Rights Cases ${ }^{132}$ and McCulloch v. Maryland. ${ }^{133}$ These cases provided broad guidance regarding both the appropriate targets of legislation and the appropriate means of addressing those targets. For example, under Ex parte Virginia, legislation was appropriate if it addressed an object of the amendment and if the legislation itself was not prohibited by the Constitution. ${ }^{134}$ The Court used a similar standard in The Civil Rights Cases, decided four years after Ex parte Virginia. There, the Court held that to be appropriate, the remedy must be "corrective in its

128. See infra notes $141-42$ and accompanying text.

129. See infra notes $144-60$ and accompanying text.

130. See id.

131. Ex parte Virginia, 100 U.S. at 345-46 (supporting denial of habeas corpus request of petitioncr, a county court judge who had excluded African Americans from jury lists, on grounds that the Thirteenth and Fourteenth Amendments secure the rights of African Americans to an impartial jury trial, a right that Congress, not the Courts, is cmpowered to enforce).

132. 109 U.S. 3 (1883) (holding that the first and second sections of the Civil Rights Act of 1875 were unconstitutional because they exceed Congress's Section 5 power in that they were addressed directly and primarily to private actors).

133. 17 U.S. (4 Wheat.) 316 (1819) (upholding a broad interpretation of Congress's powcrs under the Constitution by finding that Congress had the power to charter a central bank for the United States).

134. See Ex parte Virginia, 100 U.S. at 345-46. 
character, adapted to counteract and redress the operation of such prohibited State laws or proceedings of State officers."135

The basis for discerning appropriate legislation as expressed in $E x$ parte Virginia and The Civil Rights Cases, however vague, followed in the footsteps of the ends-justifies-appropriate-means language of $\mathrm{McCulloch} v$. Maryland. ${ }^{136}$ Together, these three cases provided a standard for determining appropriate legislation for over a century. For example, in modern cases such as South Carolina v. Katzenbach and Morgan, the Court continued to cite to Ex parte Virginia's appropriate legislation standard and also likened the "appropriate legislation" standard for Section 5 to the standard established for the Necessary and Proper Clause ${ }^{137}$ by Chief Justice Marshall in McCulloch: "Let the end be legitimate, let it be within the scope of the constitution, and all means which are appropriate, which are plainly adapted to that end, which are not prohibited, but consist with the letter and spirit of the constitution, are constitutional."138 Even in City of Rome, decided one hundred years after Ex parte Virginia, the Court still cited to $\mathrm{McCulloch}$ and Ex parte Virginia for the appropriate legislation standard. ${ }^{139}$ In the cases using this standard, the Court exhibited significant deference to Congress, regardless of the comprehensiveness of the accompanying legislative record. If the Court could "perceive a basis upon which Congress might predicate a judgment ${ }^{3140}$ that the activity to be regulated was unconstitutional, then the legislation would be deemed to be appropriate.

The Court's standard did not change until City of Boerne, decided two years after Brzonkala's suit against Morrison had commenced in district court. In City of Boerne, the Court articulated the "congruence and proportionality" test, under which appropriate legislation must have a "congruence and proportionality between the injury to be prevented or remedied and the means adopted to that end."141 While the precise meaning of the City of Boerne test remains opaque, ${ }^{142}$ subsequent cases applying the

135. Civil Rights Cases, 109 U.S. at 18.

136. See McCulloch, 17 U.S. (4 Wheat.) at 421.

137. U.S. ConsT. art. I, \$ 8, cl. 18.

138. See South Carolina v. Katzenbach, 383 U.S. at 358; Morgan, 384 U.S. at 650.

139. City of Rome v. United States, 446 U.S. 156, 177 (1966) ("It is clear, then, that under $\S 2$ of the Fifteenth Amendment Congress may prohibit practices that in and of themselves do not violate $\$ 1$ of the Amendment, so long as the prohibitions attacking racial discrimination in voting are 'appropriate,' as that term is defined in McCulloch v. Maryland and Ex parte Virginia ....").

140. Katzenbach v. Morgan, 384 U.S. 641, 656 (1966).

141. City of Boerne, 521 U.S. at 520. Several commentators have doubted the constitutional basis of the congruence and proportionality test. See, e.g., Evan H. Caminker, "Appropriate" Means-Ends Constraints on Section 5 Powers, 53 STAN. L. Rev. 1127 (2001); Caminker, Private Remedies, supra note 11, at 1373-74; Estreicher \& Lemos, supra note 7, at 153-56.

142. See, e.g., Caminker, "Appropriate" Means-Ends Constraints, supra note 141, at 1153 ("Throughout Boerne and its progeny, the Supreme Court never clearly defined the distimctive 
test reveal that the Court has essentially separated the appropriate legislation analysis into two parts: an analysis of the appropriateness of the targets of legislation and a consideration of the appropriateness of the means by which the harm is remedied..$^{143}$

\section{Appropriate Targets and the Enforcement Rationale}

City of Boerne focused primarily on the appropriateness of the harm Congress addressed through the enactment of RFRA. The City of Boerne Court explained that the congruence and proportionality test ensures that the power to discern the substance of a constitutional violation (the province of the Court) will remain separate from the power to prevent or remedy unconstitutional action (the province of Congress). ${ }^{144}$ In other words, the congruence and proportionality test guarantees that Congress does not "decree the substance of the Fourteenth Amendment's restrictions on the States." 145 The test made sense for the case at hand since in City of Boerne, Congress enacted the RFRA in direct defiance of the Court's holding in Oregon v. Smith. ${ }^{146}$

City of Boerne suggested that findings were important for determining the appropriateness of the harm addressed by Congress. Indicating that a sufficient legislative record may have persuaded the Court to find RFRA constitutional, the Court ruled that Congress had not provided enough factual data to establish that the legislation was appropriate. ${ }^{147}$ RFRA failed because the record did not indicate that RFRA corresponded "to a supposed remedial or preventive object so as to be understood to be responsive to, or designed to prevent, unconstitutional behavior."148

While City of Boerne did not clarify how extensive findings must be to establish the existence of an appropriate harm, ${ }^{149}$ City of Boerne provided modest guidance by offering South Carolina v. Katzenbach and Morgan as examples of cases in which there were appropriate harms. ${ }^{150}$

meanings of, or requirements imposed by, the two components of the composite phrase 'congnuence and proportionality."); Post \& Siegel, supra note 7, at 458 ("[T]he Boerne test never specifies how much congruence and proportionality is constitutionally necessary.").

143. See infra notes $144-60$ and accompanying text.

144. See City of Boerne, 521 U.S. at 527-30.

145. Id. at 519 .

146. See supra notes $101-05$ and accompanying text.

147. City of Boerne, 521 U.S. at 530 ("RFRA's legislative record lacks examples of modern instances of generally applicable laws passed because of religious bigotry.").

148. Id. at 532 .

149. See Bryant \& Simeone, supra note 11, at 347 ("[T]he Flores Court assiduously preserved ambiguity as to the ultimate siguificance or necessity of legislative findings of fact."). Even with the lack of clarity of the scope of the findings requirement under City of Boerne, 1 argue that City of Boerne did not significantly implicate congressional power, since the prophylactic and enforcement rationales of the early cases remained intact. See supra notes 144-60 and accompanying text.

150. City of Boerne, 521 U.S. at 518. 
The City of Boerne Court acknowledged that in South Carolina v. Katzenbach Congress had responded to "historical experience"151 and that Congress established evidence in the record reflecting the subsisting and pervasive discriminatory, and therefore unconstitutional, use of literacy tests. ${ }^{152}$ Although congressional findings were negligible in Morgan, ${ }^{153}$ the City of Boerne Court cited to the Morgan Court's holding that "Congress had a factual basis on which to conclude that New York's literacy requirement "constituted an invidious discrimination in violation of the Equal Protection Clause."'154

South Carolina v. Katzenbach and Morgan suggest that the evaluation of an appropriate harm requires two steps: first, that Congress collect a set of data; second, that Congress apply the Court's legal rules to determine whether a harm exists. As Professor Frickey explains:

To be sure, a factual assessment is essential .... In the end, however, what is called for is a legal conclusion-a conclusion with the force of law, rather than a factual conclusion-based on the application of a legal standard to the best assessment of facts available. The process can be broken down into its constituent parts: the articulation of a legal standard, and then the application of that standard to the available facts. ${ }^{155}$

Alternatively, Professor Cox describes Congress's evaluative process as one in which "the finding of facts ... cannot really be severed from their characterization or evaluation for legal purposes . . .."156 Under both Professor Frickey's and Professor Cox's depiction of the congressional process of evaluating facts, the appropriate harm analysis propagates the enforcement primciple: Congress must apply the Court's legal rules to the data it collects in order to establish the existence of an appropriate harm.

\section{Appropriate Remedies and the Prophylactic Rationale}

In City of Boerne, the Court was more concerned with appropriate harms than with appropriate remedies for those harms. ${ }^{157}$ Yet City of Boerne does give some insight into what the Court considers to be an appropriate remedy. Most importantly, the City of Boerne Court noted that

151. Id. at 525 .

152. Id.

153. See supra notes $84-86$ and accompanying text.

154. City of Boerne, 521 U.S. at 527 (quoting Morgan, 384 U.S. at 656).

155. Frickey, supra note 16 , at 714-15.

156. Cox, supra note 91 , at 234.

157. City of Boerne, 521 U.S. at 532 ("RFRA is so out of proportion to a supposed remedial or preventive object that it cannot be understood as responsive to, or designed to prevent, unconstitutional behavior. It appears, instead, to attempt a substantive change in constitutional protection."). 
prophylactic legislation may be appropriate "when there is reason to believe that many of the laws affected by the congressional enactment have a significant likelihood of being unconstitutional." 158 The City of Boerne Court's citation to Morgan, a case where the legislation was accompanied by almost no legislative findings, as an example of legislation meeting the appropriateness test demonstrates that City of Boerne implicitly retained the prophylactic rationale in its conceptualization of appropriate remedies.

Second, the City of Boerne Court twice used language suggesting that the appropriateness of a remedy may depend on the seriousness of the harm. First, the Court stated that appropriate legislation requires "congruence between the means used and the ends to be achieved." 159 Second, it also claimed that "[s]trong measures appropriate to address one harm may be an unwarranted response to another, lesser one." 160 The language suggests that the Court may view congressional findings that were gathered to establish the existence of an appropriate harm to discern whether the remedy chosen is appropriate. At the same time, because City of Boerne retains the prophylactic rationale, it suggests that findings showing serious harm in one region may be sufficient to establish that legislation covering a broader geographic area may still be appropriate. As described below, this possibility is curtailed by Morrison's finding requirement.

\section{B. Morrison's Findings Requirement: Removal of the Prophylactic} Rationale from the Appropriate Remedy Analysis

In Morrison, there appeared to be no question that $\S 13981$ was addressed to an appropriate harm. As described above, ${ }^{161}$ to establish the existence of an appropriate harm, Congress must first collect a set of data and then apply the Court's legal rules to that data. For $\S 13981$, Congress properly undertook both tasks: it documented examples showing unconstitutional bias against victims of gender-based violence from at least twentyone states $^{162}$ and made its own findings about pervasive gender-based stereotypes that impede many state legal systems. ${ }^{163}$ Nowhere in Morrison

158. Id. at 532 .

159. Id. at 530 .

160. Id. (citing South Carolina v. Katzenbach, 383 U.S. 301, 334 (1966)).

161. See supra notes $150-57$ and accompanying text.

162. See Morrison, 529 U.S. at 666 (Breyer, J., dissenting). But see Brzonkala v. Virginia Polytechnic Inst. and State Univ., 169 F.3d 820, 884 (4th Cir. 1999) (en banc) ("Even if we were to concede that the legislative history detailed state discrimination of some sort, the record recites few, if any, specific findings that the States are engaging in unconstitutional discrimination against women in the enforcement or application of their criminal and civil laws.").

163. See Morrison, 529 U.S. at 666 (Breyer, J., dissenting). See also S. Rep. No. 197 (1991) at 2728 and S. 11, 103d Cong., 1st Sess., findings 4, 7, 8 (1993). 
did the Court allege that Congress failed to employ the Court's legal rules regarding gender discrimination in evaluating its data.

Thus, the Court struck down $\$ 13981$ not because the harm was inappropriate for legislation, but because Congress chose an inappropriate remedy to address this harm; the Court found $\S 13981$ to be an inappropriate remedy because it was not addressed to a state actor ${ }^{164}$ and because it was different from other remedies in that it applied uniformly throughout the nation without findings of national harm.

Morrison is the only Section 5 case in which the Rehnquist Court has found legislation to be inappropriate because of its remedy. By contrast, in the other three recent post-City of Boerne Section 5 cases, the Court struck down legislation because proof of an appropriate harm was lacking. ${ }^{165}$ Thus, the focus on findings in Morrison is novel; there are no other cases in which the Court has held that the proffered findings were insufficiently geographic in scope, rather than imsufficiently persuasive of unconstitutional behavior.

The fact that $\S 13981$ was found to be an inappropriate remedy has three significant implications for future determinations of the appropriatness legislation. First, just as City of Boerne gave little guidance regarding the quantity of findings required to establish an appropriate harm, ${ }^{166}$ Morrison does not clarify what makes findings sufficicntly "national" to constitute an appropriate remedy. Will facts from twenty-six states suffice? Or is evidence from all fifty states now required?

Second, the unprecedented weight Morrison places on the geographic scope of findings calls into question the Court's summation of Congress's ability to evaluate what constitutes appropriate legislation. Whether the requirement is read as demanding findings for all or for most jurisdictions to be regulated, Morrison's findings requirement suggests that the Court questions Congress's ability to perceive a link between the seriousness of a harm and the remedy needed to address it. By contrast, in Morgan, the Court was not troubled by the conclusions Congress made regarding the potential unconstitutionality of conduct documented in its factual record; the Court was satisfied by data showing that the conduct to be regulated was potentially unconstitutional. ${ }^{167}$

Morrison's findings requirement ignores the reality that while evaluatmg the appropriateness of legislation, Congress relies on facts other than those it presents in its legislative history. As Professor Cox explains: "[T]he fundamental basis for legislative action is the knowledge, 
experience, and judgment of the people's representatives only a small part, or even none, of which may come from hearings and reports of committees or debates upon the floor."168 The weight Morrison's findings requirement places on geographic comprehensiveness infringes upon Congress's ability to evaluate the appropriateness of its legislation and undermines the prophylactic rationale the Court developed in the landmark Enforcement Clause cases. Morrison's findings requirement disregards the potential of some facts to have not only the quality of proof, but of prescience. Professor Kenneth Karst explains: "[J]udges know that constitutional decisions speak principally to the future, so that legislative facts often must be in the nature of predictive opinions." 169 In other words, Morrison's findings requirement discounts the reasonableness of inferring that serious harms similar to those established in the data set are likely to occur in other geographic areas.

Finally, Morrison's findings requirement can also be read to suggest that the Court considers some realms of legislation to be inore appropriate than others. This implication would intimate that the sentence, "Strong measures appropriate to address one harm may be an unwarranted response to another, lesser one," 170 may have a meaning different from that suggested above. ${ }^{171}$ Perhaps the Court intended to say that for some harms, such as voting rights discrimination, strong measures are appropriate, whereas for other harms, such as gender discrimination, such measures are not appropriate. This allegation, though concededly provocative, seems at least partly well-founded, since the statutes in Morgan and Rome were each upheld on the basis of a factual record that was much less developed than the record for $\S 13981$. The allegation is also supported by the fact that the Court reviews congressional involvement in different areas of substantive law with different levels of scrutiny. For example, scholars have noted that the standard the Court applies to review congressional enforcement of the Civil War amendments is higher than the standard the Court applies for congressional enforcement of its Commerce Clause power, ${ }^{172}$ scholars also argue that in realms of heightened scrutiny (such as race and gender), the Court is right to employ a higher standard to adjudge the persuasiveness of

168. Cox, supra note 15 , at 105.

169. Kenneth L. Karst, Legislative Facts in Constitutional Litigation, 1960 Sup. Cr. REv. 75, 103 (1960).

170. City of Boerne, 521 U.S. at 530.

171. See supra note 160 and accompanying text (arguing that the findings of harm dictate what remedies are appropriate).

172. See Cox, supra note 91, at 219 (noting the different standards); Frickey, supra note 16, at 717-18 (explaining that the difference is "probably explained mostly by the desires to avoid labeling state and local governments racist except on clear evidence and to avoid asking judges essentially to take on a legislative function by balancing the harms resulting from discriminatory effects against whatever justifications there might be for government decisions causing those effects). 
facts. ${ }^{173}$ Looked at in light of the developinent of the jurisprudence on appropriate legislation, Morrison's findings requirement suggests that the standard the Court applies to review congressional enforcement of prophylactic gender legislation is stricter than the standard it applies to review prophylactic voting rights legislation. This assertion is not meant to diminish the importance of the Court's treatment of voting rights legislation, nor does it ignore the fact that City of Rome dealt with the Enforceinent Clause under the Fifteenth Amendinent while Morrison deals with that of the Fourteenth Amendment. This is only to say that there appears to be little principled basis for the difference in the Court's treatment of voting rights and gender; since the Voting Rights Act was predicated on the achievement of equality for the races, ${ }^{174}$ and, further, since both race and gender face a form of heightened scrutiny, ${ }^{175}$ it seems that a comparable volume of data should be allowed to establish the appropriateness of legislation, whether the context is race or gender. The implications of the barriers that impede the enactment of gender legislation are pursued inore fully in Part IV.

\section{IV \\ Enforcing the Provisions of Section I}

"In its core meaning, ... the equal 'protection' of the laws was designed to ensure that the criminal justice system would protect black people, no less than whites, against crimes." VAWA, the Committee reports state, was based on a similar premise, albeit one expressed in different terms. The bill was intended to respond to state laws and practices that protected women less than men-not because women were not covered by general criminal provisions but because those criminal provisions were understood and applied differently to most common crimes against women.

Victoria Nourse ${ }^{176}$

173. See, e.g., Jeffrey M. Shaman, Constitutional Fact: The Perception of Reality by the Supreme Court, 35 U. FLA. L. REv. 236, 245 (1983) (describing the context of the Court's heightened scrutiny of "constitutional facts").

174. See, e.g., South Carolina v. Katzenbach, 383 U.S. at 308 ("The Voting Rights Act was designed by Congress to banish the blight of racial discrimination in voting, which has infected the electoral process in parts of our country for nearly a century.").

175. See Adarand Constructors, Inc. v. Pena, 515 U.S. 200, 247 (1995) (Stevens, J., dissenting) ("[T]he Court will apply 'intermediate scrutiny' to cases of invidious gender discrimination and 'strict scrutiny' to cases of invidious race discrimination.").

176. Nourse, supra note 51, at 23-24 (quoting a written statement of Professor Cass Sunstein mcluded in Violence Against Women: Victims of the System: Hearing Before the Comm. on the Judiciary, 102d Cong., 1st Sess. 369, at 118 (1991)). 
Congress's authority to enact legislation under Section 5 of the Fourteenth Amendment is the power "to enforce ... the provisions of this article." 177 For Morrison, the relevant "provision" is the Equal Protection Clause of Section 1, which provides: "No State shall... deny to any person within its jurisdiction the equal protection of the laws."178 Thus, in order to exercise its authority to enact Section 5 legislation, Congress must first consider whether the Equal Protection Clause of Section 1 has been violated. This Part outlines the Section 1 rules that apply to gender equal protection cases, as well as Congress's method of inquiring into whether a violation has occurred. The Casenote then considers how Morrison's findings requirement changes the Section 1 analysis.

A. The Court's Characterization of Section 1 Rules for Gender Discrimination: From Intermediate to Heightened Scrutiny

In performing a Section 1 analysis to determine whether state practices towards women violate the Equal Protection Clause, Congress must apply the Section 1 rules the Court has established for plaintiffs who challenge state conduct or legislation as being unconstitutionally discriminatory on the basis of gender. ${ }^{179}$ A Section 1 litigant must first establish a prima facie case of gender discrimination. ${ }^{180}$ The burden then shifts to the State to assert that its practices meet the test applied in gender cases: that the activity was substantially related to an important government interest. ${ }^{181}$

Neither the majority opinion nor either of the dissenting opinions analyzes whether the states' record in addressing gender-based violence constitutes discrimination under the standards of Section $1 .{ }^{182}$ Yet, reading between the lines in Morrison, the Court may have found a Section 1 harm had it performed the analysis. The majority's language expresses a certain

177. U.S. ConsT. amend. XIV, § 5 .

178. Id. amend. XIV, $\S 1$.

179. For a history tracing the evolution of the rules governing Section 1 claims of gender discrimination, see Christina DeJong \& Christopher E. Smith, Equal Protection, Gender, and Justice at the Dawn of a New Century, 14 WIS. Women's L.J. 123 (1999).

180. For an example of a case where a plaintiff established a cause of action against a city and city officers for failing to address gender-motivated violence and thus failing to provide equal protection of the laws, see Thurman v. City of Torrington, 595 F. Supp. 1521, 1530 (1984) (denying defendants' motion to dismiss and holding that plaintiff had established a cause of action against the City of Torrington and Torington police officers because defendants had adopted a practice of not responding to domestic violence against women, and that this practice amounted to an administrative classification for which the City was unable to provide an important governmental interest, in violation of the Equal Protection Clause).

181. See Craig v. Boren, 429 U.S. 190, 197 (1976).

182. It is also interesting to note that Justice Ginsburg, who litigated many of the landmark gender cases in front of the Supreme Court before becoming a Supreme Court Justice, did not join Justice Breyer's dissenting opinion regarding the majority's Section 5 holding. See Morisson, 529 U.S. at 655 (Breyer, J., dissenting). 
conviction about the persuasiveness of Congress's evidence: "Petitioners' $\S 5$ argument is founded on an assertion that there is pervasive bias in various state justice systems against victims of gender-motivated violence. This assertion is supported by a voluminous congressional record."183 Also, as discussed above, the only holding of the en banc Fourth Circuit that the majority did not affirm was the holding that Congress did not design $\S 13981$ as a remedy for purposeful discrimination against women by hostile state courts. This indicates that the majority did not share the view of the Fourth Circuit. ${ }^{184}$

Morrison may be maddening for those who believe that every constitutional violation should have a remedy. To this, some might respond that the constitutional violations at issue here may have a remedy, just not the one provided by $\S 13981$. The text of Section 1 itself can be read to suggest that $\S 13981$ is mappropriate, in that the text refers to "States"185 whereas $\S 13981$ is addressed to private individuals. ${ }^{186}$ As far as the reasoning to strike $\S 13981$ is based in the text of the Constitution, the holding may be justified. Yet if the reasoning for the holding is grounded in the lack of findings from all, or most, states, the Section 1 analysis seems to lend no justification for the holding.

Or is there something about Section 1 and the gender context that lends it to increased scrutiny of the legislative record? Citing to the "intermediate scrutiny" test articulated in Craig v. Boren, ${ }^{187}$ which asks whether the sex-based discrimination is substantially related to an important governmental interest, Professor Frickey writes that " $[t]$ his standard contemplates a judicial inquiry into the legislative process, for it seeks to evaluate the actual governmental objective that motivated the legislature." 188 Yet even if it is true that the intermediate scrutiny standard inspires an increased scrutiny of gender discrimination cases, this cannot explain what is going on im Morrison. In Morrison, the Court did not engage in the Section 1 analysis, so it is not the intermediate scrutiny standard, as Professor Frickey might suggest, that imspires the Court's heightened scrutiny of Congress's legislative record. Two possibilities thus arise: either the findings requirement has nothing to do with the Section 1 analysis, or, to the contrary, the findings requirement has everything to do with this Section 1 analysis, or lack thereof.

183. Id. at 619-20.

184. Even if the Court would not have found a Section 1 violation, $\$ 13981$ was nevertheless an appropriate exercise of Section 5 power under the prophylactic rationale of Morgan. See supra notes 83-86 and accompanying text.

185. See supra note 178.

186. See supra note 51 and accompanying text.

187. 429 U.S. 190, 197 (1976).

188. Frickey, supra note 16, at 724 . 
In terms of the first possibility, it is conceivable that the findings requirement announced in Morrison has nothing to do with gender; perhaps it was just coincidence that Morrison came along during the Court's trend of increasing its scrutiny of legislative facts. ${ }^{189}$ In terms of the second possibility, perhaps there is something significant to the fact that the Court announced this findings requirement first in a prophylactic gender case. Although the majority referred to the Craig $v$. Boren standard as the applicable test, ${ }^{190}$ it actually cited to United States $v$. Virginia. ${ }^{191}$ In that case, Justice Ginsburg employed what has come to be called "heightened scrutiny." 192 That the standard for gender discrimination might not be simply "intermediate scrutiny" has also been acknowledged im other cases. ${ }^{193}$ In addition, the Justices have commented on the inconsistency im the Court's treatment of federal race and gender affirmative action programs. ${ }^{194}$ Thus, it appears that remedies for Section 1 gender discrimination, whether remedial or prophylactic, are receiving something closer to strict, rather than intermediate, scrutiny. Put another way, the screw is tightening wherever gender legislation is concerned, and Morrison's heightened findings requirement fits right into this pattern.

\section{B. Morrison's Findings Requirement: Heightening the Scrutiny of} Future Section I Analyses

By avoiding the Section 1 analysis, the Supreme Court prolonged the uncertainty regarding the standard that applies to prophylactic gender legislation. Yet, at the same time, the findings requirement makes the burden of proof on Congress higher than it would be if only the established Section 1 rules were to apply. Under the intermediate scrutiny standard, a gender

189. See supra note 16.

190. See Morrison, 529 U.S. at 620.

191. 518 U.S. 515 (1996).

192. See, e.g., Cohen v. Brown University, 101 F.3d 155, 191 (1st Cir. 1996) ("[T] Court appears to have elevated the test applicable to sex discrimination cases to require an 'exceedingly persuasive justification.' This is evident from the language of both the majority opinion and the dissent in Virginia.").

193. See J.E.B. v. Alabama, 511 U.S. 127, 137 n.6 (1994) ("Because we conclude that gender-based peremptory challenges are not substantially related to an important government objective, we need not decide whether classifications based on gender are inherently suspect."); Harris v. Forklift Systems Inc., 510 U.S. 17, $26 \mathrm{FN}^{*}$ (1993) ("[I]t remains an open question whether 'classifications based on gender are inherently suspect."').

194. See, e.g., Adarand Constructors, Inc. v. Pena, 515 U.S. 200, 247 (1995) (Stevens, J., dissenting) (" $[\mathrm{A}] \mathrm{s}$ the law currently stands, the Court will apply 'intermediate scrutiny' to cases of invidious gender discrimination and 'strict scrutiny' to cases of invidious race discrimination, while applying the same standard for benign classifications as for invidious ones. If this remains the law, then today's lecture about 'consistency' will produce the anomalous result that the Government can more easily enact affirmativc-action programs to remedy discrimination against women than it can enact affirmative action programs to remedy discrimination against African Americans."). 
classification must be substantially related to an important government interest. ${ }^{195}$ Under this standard, there is room for the classification to be somewhat over- or underinclusive. ${ }^{196}$ In contrast, at least under the first of the two likely readings of Morrison's findings requirement (where Congress must present findings of harm that have an exact one-to-one correspondence with the scope of its legislation), the Court appears to have raised the standard of review for prophylactic gender legislation to something closer to strict scrutiny, whereby there can be no over- or underinclusiveness between the means chosen and the objectives of the legislation. ${ }^{197}$

Since Section 5 requirements seem to be more lenient than, or at most, equivalent to, the requirements under Section $1,,^{198}$ a subsequent question arises: will lower courts hold Section 1 litigants to the same heightened standards to which the Court held Congress in Morrison? Consider a scenario in which a woman brings a claim against a nlan under a prophylactic state gender discrimination statute, and the man challenges the statute as discriminatory against him and thereby unconstitutional under Section 1. If the lower court adopts the first reading of Morrison's findings requirement, would the court rule that unless the remedy provided by this prophylactic state statute precisely mirrors the harm in the state, the remedy is unconstitutional? Simply put, will lower courts impose a Morrison-like fnidings requirement on prophylactic state legislation contested under Section 1?

Because Morrison's findings requirement is directed to Congress under Section 5 rules, lower courts are under no obligation to read a findings requirenient into any state legislation challenged under Section 1 . Nevertheless, courts are concerned with symmetry and may thus read the requirement into such legislation even if they not required to do so. For example, when confronted with a similar confiict between a Section 1 standard and a statutory standard, the Eleventh Circuit recently ruled that the stricter standard should be employed. ${ }^{199}$ In that case, the Eleventh Circuit noted the conflict between the evidentiary showings required under

195. See Craig v. Boren, 429 U.S. 190, 197 (1976).

196. See Associated Gen. Contractors of California v. City and County of San Francisco, 813 F.2d 922, 941-42 ("Unlike racial classifications, which must be 'narrowly' tailored to the government's objective ... there is no requirement that gender-based statutes be 'drawn as precisely as [they] might have been."' (citations omitted)).

197. See Wygant v. Jackson Bd. of Educ., 476 U.S. 267, 280 (1986) ("Under strict scrutiny the means chosen to accomplish the state's asserted purpose must be specifically and narrowly framed to accomplish that purpose.").

198. See Metro Broad., Inc. v. FCC, 497 U.S. 547, 563 (1990) (asserting the appropriateness of the Court's adoption of deference where the program at issue has been approved and mandated by Congress).

199. In re Employment Discrimination Litig. Against Ala., 198 F.3d 1305, 1322 (11th Cir. 1999). See also Post \& Siegel, supra note 7, at 452. 
Section 1 and Title VII claims: a Section 1 claim requires a showing of discriminatory purpose, while a Title VII claim requires a lesser showing of disparate impact. The Eleventh Circuit reconciled the two standards by ruling that both causes of action demand an inquiry into "discriminatory intent." ${ }^{200}$ Effectively, the Eleventh Circuit held a Title VII plaintiff to the stricter Section 1 standard. ${ }^{201}$

If a higher level of scrutiny similarly were imported into Section 1 because of Morrison's findings requirement, states would encounter greater barriers to their enactment of prophylactic gender discrimination legislation. If this occurs, the Supreme Court would be the instrument of a perverse result. While notions of federalisin and states' rights animate the Supreme Court's decision in Morrison, ${ }^{202}$ the Court would itself be tying the hands of states that desire to enact prophylactic gender legislation. This implication is discussed in the next, concluding Part.

\section{CONCLUSION}

Why is the remedy "disproportionate"? And given the relation between remedy and violation - the creation of a federal remedy to substitute for constitutionally inadequate state remedies-where is the lack of "congruence"? ... Why can Congress not take the evidence before it as evidence of a national problem?

Justice Breyer, dissenting in United States v. Morrison ${ }^{203}$

Morrison's findings requirement significantly alters each of the three key elements of Section 5. Morrison curtails Congress's Section 5 power by tying that power to a new findings requirement that did not exist in the foundational Enforcement Clause cases. Moreover, by making the showing of unconstitutional conduct a prerequisite to enacting legislation, Morrison's findings requirement undermines the prophylactic and enforcement rationales underlying the landmark cases. The findings requirement also deflates Congress's Section 5 power from a positive grant of legislative power worthy of deference to one that essentially comprises

200. In re Employment Discrimination Litig. Against Ala., 198 F.3d at 1322.

201. Note that even before Morrison, some lower courts had already applied a standard stricter than the intermediate scrutiny standard to prophylactic gender legislation. See Conlin v. Blanchard, 890 F.2d 811, 816 (6th Cir. 1989) ("In order for a race or sex based remedial measure to withstand scrutiny under the fourteenth amendment there must first be some showing of prior discrimination by the governmental entity involved, and second, the remedy adopted by the state must be tailored narrowly to achieve the goal of righting the prior discrimination."); Am. Subcontractors Ass'n v. City of Atlanta, 376 S.E.2d 662, 664 (Ga. 1989) (appearing to apply strict scrutiny to both the race and gender aspects of the affirmative action program).

202. Morrison, 529 U.S. at 615-19.

203. Id. at $665-66$. 
little more than a factfinding function. The requirement thereby demeans the nature of Congress's work by prioritizing factfinding over its legislative responsibilities.

In terms of the appropriateness of legislation, Morrison's findings requirement threatens Congress's ability to make its own conclusions regarding the constitutional ramifications of the data it has collected and when regarding legislation is appropriate. In addition, because of the undue weight the requirement places on findings of unconstitutional conduct, the requirement also threatens the enactment of prophylactic legislation. Finally, since the findings for $\S 13981$ were at least as extensive as those provided in the voting rights cases, Morrison's findings requirement seems to suggest that realms of congressional action other than gender are more appropriate for legislation.

The Morrison Court did not meaningfully consider the final key element of Section 5, the Section 1 analysis. The Court may have avoided the analysis because of the uncertainty about the level of scrutiny that should apply to prophylactic legislation. Although the Court did undertake a Section 1 analysis, Morrison may nevertheless impact future Section 1 analyses in two distinct ways. First, given that the standards Congress must meet to enact legislation under Section 5 traditionally have been less strict than what was required for a litigant under Section $1,{ }^{204}$ the question arises whether Morrison's findings requirement will be transposed to Section 1 jurisprudence. In addition, since there can be little or no over-inclusiveness in the remedy applied, Morrison's universal findings requirement appears to shift the level of scrutiny im gender discrimination from intermediate scrutiny to something akin to strict scrutiny. Whether the Supreme Court will apply such a standard under Section 1 remains to be seen.

Given the majority opinion's lack of coherence with previous Section 5 jurisprudence, lower courts are likely to interpret Morrison in inconsistent ways. For example, lower courts may vary in the level of scrutiny to which states' prophylactic gender legislation is subjected and may vary in the scope of findings they require of state legislatures.

Steps should be taken to mitigate the implications of Morrison's findings requirement. First, the Supreme Court should directly address the findings issue. Rather than allude to a findings requirement in dicta, and rather than subjecting Congress to a requirement it has never fully articulated, the Supreme Court should acknowledge the trends in its case history and deliberately discuss the findings issue. The Supreme Court should answer the questions that have emerged regarding the scope and contours of the Section 5 findings requirement and should reconcile the findings 
requirement with Section 1 jurisprudence. In addressing these issues, the Supreme Court should acknowledge the prophylactic and enforcement rationales that underlie Section 5 jurisprudence and ensure that any findings requirement it formally makes coheres with such rationales.

Next, lower courts should understand that Morrison's findings requirement threatens the key rationales of appropriate, prophylactic legislation. Lower courts should refrain from importing Morrison into Section 1 legislation by refusing to impose findings requirements on states enacting prophylactic gender legislation.

Finally, Congress should not be deterred by Morrison. Rather, Congress should continue to address social matters in need of prophylactic legislation. Mindful of the history and force of the prophylactic and enforcement rationales, Congress should continue to employ its positive grant of legislative power and its ability to regulate that which is not unconstitutional. 